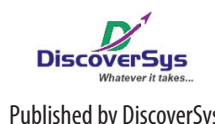

Published by DiscoverSys

\section{Association between breakfast-eating habit and attention-concentration in primary school children: a cross-sectional study in Badung District}

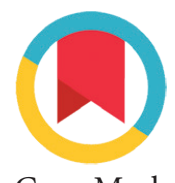

\author{
Ni Made Ari Sukmandari, ${ }^{1}$ Ni Wayan Septarini, ${ }^{2}$ \\ Gede Ngurah Indraguna Pinatih ${ }^{2}$
}

\begin{abstract}
Background and purpose: One of the main benefits of breakfasteating habit for schoolchildren is to maintain the attentionconcentration. The current trend shows a steady decline in the breakfast-eating habit among primary school children. This present study aims to examine the association between breakfast-eating habit and attention-concentration in primary school children.

Methods: A cross-sectional study was conducted involving 160 primary school students year 5 and 6 . Samples were selected from six public primary schools within two villages. There were a total of 16 classes of year 5 and 6 in these six schools, and five classes were selected randomly. All students from the selected classes included in the study. Attentionconcentration was measured using a digit symbol test, and breakfasteating habit and total calories intake were measured using the recall

24 hours and a standardised questionnaire. Multivariate analysis with logistic regression was employed to examine the association between breakfast-eating habit and attention-concentration.

Results: The majority of students were found to have good concentration (60.63\%), with breakfast-eating habit (75.00\%), and consumed sufficient amount of calories (53.13\%). Our multivariate analysis found a significant association between breakfast-eating habit and attention-concentration among schoolchildren ( $A 0 R=14.0$; 95\%Cl: 4,9-67,8).

Conclusions: Students with breakfast-eating habit tend to have a good attention-concentration. The total calories intake during breakfast is not associated with attention-concentration among primary school students in Badung District.
\end{abstract}

Keywords: Breakfast, attention-concentration, schoolchildren

Cite This Article: Sukmandari, N.M.A., Septarini, N.W. Indraguna Pinatih.G.N.I 2018. Association between breakfast-eating habit and attentionconcentration in primary school children: a cross-sectional study in Badung District. Public Health and Preventive Medicine Archive 6(1): 55-60. DOI:10.15562/phpma.v6i1.10

${ }^{1}$ Bina Usada Health Institute, Bali Province,

${ }^{2}$ Department of Public Health and Preventive Medicine, Faculty of Medicine, Udayana University

*Correspondence to:

Ni Made Ari Sukmandari, Bina Usada Health Institute, Bali Province,

arisukmandari@yahoo.co.id

\section{INTRODUCTION}

Breakfast-eating habit might improve attention-concentration among schoolchildren because carbohydrates from breakfast will increase blood glucose level and energy supply to the brain. ${ }^{1,2}$ Sufficient supply of energy to the brain increases its functions which include attention, alertness, logical reasoning, and problem solving. ${ }^{3}$ A study in Indonesia found that as many as $16.9 \%$ to $59 \%$ of schoolchildren in major cities did not regularly have breakfast before going to school. ${ }^{4}$ An analysis of the 2010 Indonesia Basic Health Research (Riskesdas) revealed that as many as $44.6 \%$ schoolchildren consumed low-quality breakfast with total calories less than $15 \%$ of the daily requirements. ${ }^{4}$ The above data suggest that breakfast-eating habit among schoolchildren in Indonesia is a serious issue, especially its effects on the academic performance.

Studies in Indonesia and other countries have documented several factors associated with breakfast-eating habit among schoolchildren as well as its effect on attention-concentration. ${ }^{5}$ These factors are age, sex, and parent education. ${ }^{6}$ Other factors which relate to attention-concentration are nutritional status, ${ }^{7}$ intelligence quotient, worm infestation, ${ }^{8}$ and anemia. ${ }^{7}$

Published literature examining the association between breakfast-eating habit and attention-concentration is limited, $, 9,10,11$ however, there are some postgraduate and undergraduate theses that investigated this association. ${ }^{12,13}$ A study in Bandung City West Java found an association between breakfast-eating habit with academic performance and cognitive function among primary school children. ${ }^{14}$ A study in Palangkaraya, Central Kalimantan found that adolescents aged 16-19 years-old with breakfast-eating habit tended to have higher attention-concentration (measured using digit symbol and digit span tests) than those without breakfast-eating habit. ${ }^{10}$ However, the above studies are still confounded by several factors which relate to attention-concentration level: age, sex, mother's education level, nutritional status, anemia status, intellectual capacity, and worm infestation. The above studies may have not accurately 
measured the independent effect of breakfast-eating habit and total calories intake during breakfast with attention-concentration among primary school children.

Our study aims to examine the association between breakfast-eating habit and total calories intake during breakfast with attention-concentration among primary schoolchildren in Badung District.

\section{METHODS}

A cross-sectional survey was conducted in April 2017 in six public primary schools in two villages (Abianbase and Buduk) at Mengwi Subdistrict, Badung District. Mengwi Sub-District was selected with a consideration that the total number of primary school children in Mengwi Subdistrict is the third highest across Badung District. These two villages were selected purposively because they are rural-urban transition areas where many of schoolchildren from other sub-districts also enrolled in these schools. This situation makes the student characteristics in these schools more diverse compared to other villages in Badung District, thus, allows a better generalisation across Badung District. The students involved in the study were those in year 5 and 6 with an assumption that they had developed logical and operational thinking ability to enable data collection processes. There were 16 classes with 530 students in those six public primary schools. Five classes were selected randomly with a total of 160 students.

The attention-concentration was measured through a standardised digit symbol test and interpreted by a child/adolescent psychologist. ${ }^{15}$ Using the mean value as a cut-off point, our data was categorised into good ( $\geq 11$ points) and poor ( $<11$ points). To obtain data on breakfast-eating habit and total calories intake during breakfast, a 24 hours recall was conducted by five nutritionists. The 24 hours recall consists of simple questions, and it was considered as an appropriate method for primary school children. Data on total calories intake during breakfast were categorised into sufficient and insufficient based on the minimum requirements of 500 calories. ${ }^{16}$ The mean value of total calories intake during breakfast was used as a cut off point and classified as sufficient ( $\geq 276$ calories) and insufficient ( $<276$ calories). Data of age, sex, mother's education, and class were collected through interview. Data on worm medication was obtained from the public health centre (PHC), while anemia status was defined from eye examination conducted by a medical doctor from the PHC. The intelligence quotient was measured using a standardised culture fair intelligence test (CFIT) and was interpreted by a psychologist. It was classified into high IQ score ( $\geq 93)$ and low IQ score $(<93)$. Nutritional status was measured from the weight and height to calculate the body mass index based on age 18 which then classified into normal (z-score $\pm 2 S D)$, underweight (z-score $<-2 S D)$, and obese/overweight ( $\mathrm{z}$-score $>2 \mathrm{SD}$ ).

Written informed consent was obtained from the children and their parents. Informed consent was provided to the students and they were asked to pass it to their parents for the participation approval. Parents were asked to sign the form if they allowed their children to participate in the study.

Data were analysed using STATA SE 12.1. Multivariate analysis with a backward method logistic regression was apllied to examine the association between breakfast-eating habit and attention-concentration. This study has obtained ethical clearance from the Human Research Ethics Committee Faculty of Medicine Udayana University/Sanglah General Hospital Denpasar in 2017.

\section{RESULTS}

Table 1 shows the attention-concentration, breakfast-eating habit and calories intake, sociodemographic characteristics, health status, and intelligence quotient of the respondents. The majority of respondents had a good attention-concentration $(60.63 \%)$ and had had breakfast before going to school $(75 \%)$. When compared to the recommended calories intake during breakfast, the majority of the respondents (83.75\%) had calories intake below the minimum requirement. However, compared to the group average for total calories intake during breakfast, $53.13 \%$ of respondents had calories intake above the average.

Table 2 shows that the proportion of students who had breakfast before going to school (74.1\%) had a significantly higher proportion of good attention-concentration $(p<0.001)$ than those who had no breakfast (20.0\%). The proportion of children who had total calories intake equal and above the group average $(73.81 \%)$ had a significantly higher proportion of good attention-concentration $(\mathrm{p}=0.003)$ than those who had total calories intake lower than the group average (46.05\%).

However, based on the recommended calories intake during breakfast, there is no significant difference of good attention-concentration proportions ( $\mathrm{p}=0.156)$ between students who had sufficient calories intake (73.28\%) compared to those who had insufficient intake (52.08\%). This study found that the proportion of non-anemic students had significantly higher proportion of good attention-concentration $(\mathrm{p}=0.046)$ compared to anemic 
Table 1 Attention-concentration, breakfast-eating habit, calories intake, sociodemographic characteristics, health status, and intelligence quotient of respondents

\begin{tabular}{|c|c|c|}
\hline Variable & $\mathbf{n}$ & $\%$ \\
\hline \multicolumn{3}{|l|}{ Attention-concentration } \\
\hline Good & 97 & 60.63 \\
\hline Poor & 63 & 39.38 \\
\hline \multicolumn{3}{|l|}{ Breakfast-eating habit } \\
\hline Yes & 120 & 75.00 \\
\hline No & 40 & 25.00 \\
\hline \multicolumn{3}{|c|}{ Calories intake (based on the recommended standard) } \\
\hline Sufficient ( $\geq 500$ calories) & 26 & 16.25 \\
\hline Insufficient ( $<500$ calories $)$ & 134 & 83.75 \\
\hline \multicolumn{3}{|c|}{ Calories intake (based on the group average) } \\
\hline Sufficient ( $\geq 276$ calories) & 84 & 53.13 \\
\hline Insufficient ( $<276$ calories) & 76 & 46.88 \\
\hline \multicolumn{3}{|c|}{ Age (based on the group average) } \\
\hline$\geq 11$ years & 97 & 58.75 \\
\hline$<11$ years & 63 & 39.38 \\
\hline \multicolumn{3}{|l|}{ Sex } \\
\hline Female & 94 & 43.03 \\
\hline Male & 66 & 41.25 \\
\hline \multicolumn{3}{|l|}{ Mother's education } \\
\hline High & 27 & 16.88 \\
\hline Moderate & 123 & 76.88 \\
\hline Low & 10 & 6.25 \\
\hline \multicolumn{3}{|l|}{ Anemia status } \\
\hline No & 146 & 91.25 \\
\hline Yes & 14 & 8.75 \\
\hline \multicolumn{3}{|l|}{ Worm medication history } \\
\hline No & 160 & 100.0 \\
\hline Yes & 0 & 0.00 \\
\hline \multicolumn{3}{|l|}{ Nutritional status } \\
\hline Normal & 140 & 87.50 \\
\hline Underweight & 2 & 1.25 \\
\hline Obese/overweight & 18 & 1.25 \\
\hline \multicolumn{3}{|l|}{ Intelligence quotient (IQ) score } \\
\hline High & 78 & 48.75 \\
\hline Low & 82 & 51.25 \\
\hline Total & 160 & 100.00 \\
\hline
\end{tabular}

students, namely $63.01 \%$ vs $35.71 \%$. It is shown that there were no significant associations between the attention-concentration of children with the mother's education, children's sex, nutritional status and intelligence quotient. Multivariate analysis shows that the attention-concentration was associated with breakfast-eating habit $(\mathrm{AOR}=14.0 ; \mathrm{p}<0.001)$, anemia $(\mathrm{AOR}=4.3 ; \mathrm{p}=0.025)$, and age $(\mathrm{AOR}=1.6 ; \mathrm{p}=0.034)$.

\section{DISCUSSION}

This study shows that the proportion of children who had breakfast before going to school is relatively high (75\%), however, the total calories intake yet to reach the minimum requirements $(83.75 \%) .{ }^{16}$ When compared to the 2010 Indonesia Basic Health Research (Riskesdas), ${ }^{17}$ our study found a higher 
Table 2 The association between attention-concentration with breakfast-eating habit, total calories intake during breakfast, socio-demographic characteristics, health status, and intelligence quotient

\begin{tabular}{|c|c|c|c|c|c|c|c|}
\hline \multirow[b]{2}{*}{ Variable } & \multicolumn{2}{|c|}{ Good concentration } & \multicolumn{2}{|c|}{ Poor concentration } & \multirow{2}{*}{$\begin{array}{c}\text { p value } \\
\text { (bivariate) }\end{array}$} & \multirow[b]{2}{*}{ AOR } & \multirow{2}{*}{$\begin{array}{c}\text { p value } \\
\text { (multivariate) }\end{array}$} \\
\hline & f & $\%$ & $f$ & $\%$ & & & \\
\hline \multicolumn{8}{|c|}{ Breakfast-eating habit } \\
\hline Yes & 89 & 74.17 & 31 & 25.83 & $<0.001$ & 14.0 & $<0.001$ \\
\hline No & 8 & 20.00 & 31 & 80.00 & & & \\
\hline \multicolumn{8}{|c|}{$\begin{array}{l}\text { Total calories intake during } \\
\text { breakfast * }\end{array}$} \\
\hline Sufficient & 19 & 73.08 & 7 & 26.92 & & & \\
\hline Insufficient & 78 & 58.21 & 56 & 41.79 & 0.156 & 0.87 & 0.806 \\
\hline \multicolumn{8}{|c|}{$\begin{array}{l}\text { Total calories intake during } \\
\text { breakfast }{ }^{\star *}\end{array}$} \\
\hline Sufficient & 62 & 73.81 & 22 & 26.19 & 0.003 & 1.2 & 0.689 \\
\hline Insufficient & 35 & 46.05 & 41 & 53.95 & & & \\
\hline \multicolumn{8}{|l|}{ Age } \\
\hline$\geq 11$ years & 57 & 58.76 & 40 & 41.24 & & & \\
\hline$<11$ years & 40 & 63.49 & 23 & 39.38 & 0.046 & 1.6 & 0.034 \\
\hline \multicolumn{8}{|l|}{ Sex } \\
\hline Female & 58 & 61.70 & 36 & 38.30 & & & \\
\hline Male & 39 & 59.09 & 27 & 40.91 & 0.739 & & \\
\hline \multicolumn{8}{|l|}{ Mother's education } \\
\hline High & 17 & 62.96 & 10 & 37.04 & & & \\
\hline Moderate & 72 & 58.54 & 51 & 41.46 & 0.744 & & \\
\hline Low & 8 & 80.00 & 2 & 20.00 & 0.426 & & \\
\hline \multicolumn{8}{|l|}{ Nutritional status } \\
\hline Normal & 87 & 62.14 & 53 & 37.86 & & & \\
\hline Underweight & 1 & 50.00 & 1 & 50.00 & 0.783 & & \\
\hline Obese/overweight & 9 & 50.00 & 9 & 50.00 & 0.440 & & \\
\hline \multicolumn{8}{|l|}{ Anemia status } \\
\hline No & 92 & 63.01 & 54 & 36.99 & 0.046 & 4.3 & 0.025 \\
\hline Yes & 5 & 35.71 & 9 & 64.29 & & & \\
\hline \multicolumn{8}{|c|}{ Intelligence quotient score } \\
\hline High & 52 & 66.67 & 26 & 33.33 & & & \\
\hline Low & 45 & 54.88 & 37 & 45.12 & 0.127 & 0.9 & 0.555 \\
\hline
\end{tabular}

${ }^{*}$ Based on the recommended requirement; "based on the group average

proportion of low calories intake during breakfast among students before going to school. The 2010 Indonesia Basic Health Research (Riskesdas) reported as many as $44.6 \%$ of schoolchildren had breakfast with low-quality food and lack of calories. ${ }^{17}$ However, it should be noted that the 2010 Indonesia Basic Health Research covers a large sample size and distributed across areas in Indonesia.

This study shows that the attention-concentration was significantly associated with breakfast-eating habit, anemia, and age. Our finding is consistent with a comparative study in
Pageruyung Kendal, Central Java which found a significant difference in attention-concentration among students who had breakfast and those who had no breakfast. ${ }^{11}$ Another cross-sectional study in Kediri District East Java also found a significant association between breakfast-eating habit and attention-concentration among primary school children. ${ }^{9}$ A study conducted in England also reported that students who had no breakfast before going to school tend to have lower attention-concentration due to lack of blood glucose level. ${ }^{18}$ The study measured 
attention-concentration and memory function among students at 30,90, 150, and 210 minutes after breakfast using a random technique for four consecutive days. ${ }^{18}$

Our study found anemia also associated with attention-concentration of students. These findings were consistent with a cross-sectional study in Central Java which found a significant association between anemia and cognitive function among schoolchildren aged 9-12 years-old.?

Our study revealed that there was no association between total calories intake during breakfast with attention-concentration. Our finding is inconsistent with a cross-sectional study in Kediri District East Java which found a significant association between total calories intake during breakfast and concentration level. ${ }^{9}$ The study also found a positive association between carbohydrate, protein, vitamin, and iron intake with attention-concentration among primary school children. ${ }^{9}$ However, in contrast to our study, findings from the study are still confounded by several variables which may be associated with attention-concentration in schoolchildren.

Our study enhances the existing evidence on the importance of breakfast-eating habit before heading to school. This evidence implies the key role of parent to prepare breakfast and to remind their children to have breakfast before going to school. Education program regarding the benefits of breakfast-eating habit and minimum calories intake during breakfast should be enhanced.

The possible measurement bias (internal validity) of our study is in measuring anemia which used only eye examination. In addition, this study only covered limited areas in two villages, thus the generalisation (external validity) of the findings into a wider population should be taken in cautions. Our study yet to investigate other factors which might influence attention-concentration among schoolchildren such as sleep quality, ${ }^{20}$ snacking habit, ${ }^{10}$ and general noise. ${ }^{21}$ These factors should be considered in future studies.

\section{CONCLUSION}

Students with breakfast-eating habit tend to have higher attention-concentration level than those without breakfast-eating habit. Total calories intake during breakfast is not associated with attention-concentration among the primary school students.

\section{ACKNOWLEDGEMENT}

We would like to thank the heads of Public Primary School 1, 2 and 3 Buduk, the heads of Public Primary
School 1, 2 and 3 Abianbase, and all respondents who had participated in our study.

\section{REFERENCES}

1. Sety LM, Paeha D. Tingkat asupan energi, protein, kebiasaan makan pagi dan prestasi belajar siswa SMP negeri 7 Kendari [Energy and protein intake, breakfast-eating habit, and school achievement among students in Public Junior High School 7 Kendari]. Jurnal Kesehatan. 2013; 4(2): 333-343.

2. Wesnes KA, Pincock C, Scholey A. Breakfast is associated with enhanced cognitive function in schoolchildren. An internet based study. Appetite. 2012; 59(3): 646-649.

3. Mahoney CR, Taylor HA, Kanarek RB, et al. Effect of breakfast composition on cognitive processes in elementary school children. Physiology and Behavior. 2005; 85(5): 635-645.

4. Hardinsyah, Aries M. Jenis pangan sarapan dan perannya dalam asupan gizi harian [Types of breakfast menu and its roles in daily nutrition]. Jurnal Gizi dan Pangan (Journal of Nutrition and Food). 2012; 7(2): 89-96.

5. Sukiniarti. Kebiasaan makan pagi pada anak usia SD dan hubungannya dengan tingkat kesehatan dan prestasi belajar [Breakfast-eating habit among primary school children and its association with health status and school achievement]. Jurnal Pendidikan Biologi Indonesia. 2015; 1(3): 29-32.

6. Sandercock GR, Voss C, Dye L. Associations between habitual school-day breakfast consumption, body mass index, physical activity and cardiorespiratory fitness in English school children. European Journal of Clinical Nutrition. 2010; 64(10): 1086-1092.

7. Sudargo T, Huriyati E, Safitri L, et al. Hubungan antara status gizi, anemia, status infeksi, dan asupan zat gizi dengan fungsi kognitif pada anak sekolah dasar di daerah endemik GAKI [Association between nutritional status, anemia, infection, and nutrient intake with cognitive function in primary school children of endemic iodine deficient areas]. Gizi Indonesia. 2012; 35(2): 126-136.

8. Samosir A. Hubungan antara derajat infeksi cacing yang ditularkan melalui tanah terhadap tingkat kecerdasan padaanak di SD negeri 067775 Kotamadya Medan [Association between soil transmitted worm infestation and intelligence quotient among students in Public Primary School 067775, Medan City]. Jurnal Biosains (Journal of Biosciences). 2015; 1(1): 1-10.

9. Wardoyo HA, Mahmudiono T. Hubungan makan pagi dan tingkat konsumsi zat gizi dengan daya konsentrasi siswa sekolah dasar [Association between breakfast-eating habit, nutrient intake, and attention-concentration among primary school children]. Media Gizi Indonesia. 2013; 9(1): 49-53.

10. Muchtar M, Julia M, Gamayanti IL. Sarapan dan jajan berhubungan dengan kemampuan konsentrasi pada remaja [Breakfast and snacking are associated with attention-concentration among adolescents]. Jurnal Gizi Klinik Indonesia. 2011; 8(1): 28-35.

11. Rahmawati DA. Perbandingan tingkat konsentrasi belajar anak sekolah dasar dilihat dari kebiasaan makan pagi [Attention-concentration function and breakfast-eating habit among primary school children]. Early Child Education Papers. 2014.

12. Susanti SAA, Sr KM, Walidah L. Hubungan kalori sarapan dengan kemampuan konsentrasi anak usia sekolah di SD Negeri 3 Canggu tahun 2012 [Association between calories intake during breakfast and attention-concentration among students in Public Primary School 3 Canggu in 2012]. Coping Ners. 2013; 1(1).

13. Domili MR. Kasim VN, Mursyidah A. Hubungan sarapan dengan konsentrasi belajar siswa di SD Negeri 76 Kota Tengah Kota Gorontalo [Breakfast-eating habit and its association with attention-concentration function among students in Pubic Primary School 76 Kota Tengah, Gorontalo City]. KIM Fakultas Ilmu Kesehatan dan Keolahragaan. 2015.3(3). 
14. Khalida E, Fadlyana E, Somasetya DH. Hubungan kebiasaan sarapan dengan prestasi belajar dan fungsi kognitif pada anak sekolah dasar [Breakfast-eating habit and its association with cognitive function and school achievement in primary school children]. Sari Pediatri. 2015; 17(2): 89-94.

15. Anastasi A, Urbina S. Tes Psikologi [Psychology Test]. Indeks. Jakarta. 2016.

16. Khomsan A. Pangan dan gizi kesehatan [Food and Health Nutrition]. Gramedia. Jakarta. 2003.

17. Ministry of Health of Indonesia. Riset Kesehatan Dasar 2010 (The 2010 Indonesia Basic Health Research). Ministry of Health of Indonesia. 2011.

18. Wesnes K a., Pincock C, Richardson D, et al. Breakfast reduces declines in attention and memory over the morning in schoolchildren. Appetite. 2003; 41(3): 329-331.

19. Ibda F. Perkembangan Kognitif: Teori Jean Piaget [Cognitive development: Jean Piaget Theory]. Intelektualita. 2015; 3(1): 27-38.
20. Andriani. Hubungan kualitas tidur terhadap konsentrasi belajar mahasiswa Akademi Kebidanan Internasional Pekanbaru tahun 2016 [Association between sleeping quality and attention-concentration function among students in the International Midwifery Academy, Pekanbaru, 2016]. Scientia Journal. 2016; 4(1): 383-390.

21. Halil A, Yanis A, Noer M. Pengaruh kebisingan lalulintas terhadap konsentrasi belajar siswa SMPN 1 Padang [Association between traffic noise and attention-concentration among students in Public Junior High School 1 Padang]. Jurnal Kesehatan Andalas (Andalas Journal of Health). 2015; 4: 53-57.

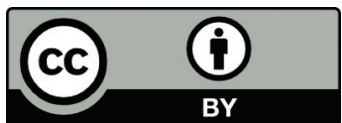

This work is licensed under a Creative Commons Attribution 